\section{WOMEN EMPOWERMENT IN DIFFERENT HOUSEHOLD ISSUES OF BANGLADESH}

Umme Rumana Zaman¹, Md. Mizanur Rahman², Syed Md Akram Hussain ${ }^{3}$, Mahbub Zaki ${ }^{4}$

\section{Abstract:}

During the last few decades, developing countries in the world has been going through an intensive transformation process related to change in demographic and in the use of human capital. These changes have important implications for women empowerment which they tend to systematically alter the marginal utility of consumption over the life cycle. Considering this view, this cross sectional study was aimed to find out the level of women empowerment in purposively selected areas of Bangladesh. A total 206 married women were interviewed face to face using structured questionnaire. To assess the level of women empowerment, a series of questions were asked with a view to assessing the level of participation in different household and family matters. On the basis of 18 variables, a composite level of women empowerment was assessed by Principal Component Analysis (PCA) using computer simulation and categorized into three groups. It was found that $40 \%$ had poor level of empowerment, $19 \%$ had fair and 41 had good level of women empowerment. Bi-variate analysis revealed that level of women empowerment was found to be high among the respondents living in urban areas, less number of children, religion Islam, higher level of education of husband and wife, working status of husband and wife, monthly family income and living in pucca house condition $(\mathrm{p}<0.05)$. However, no statistically significant association was found between current age of husband and wife, age at marriage and spousal age difference ( $p>0.05)$. Though the study had some limitations, but the study finding would be helpful for policymakers concerning implementing the programme for empowering women through different intervention programmes.

Key words: Women Empowerment, Household Decision Making, Bangladesh

\section{Introduction:}

Women are the major force behind people's participation in the life of society today. Women's participation meant their close involvement in economic, social, cultural and political process

1. Medical Officer, Renaissance Hospital and Research Institute Limited, Dhanmondi, Dhaka.

2. Associate Professor and Head, Department of Biostatistics, National Institute of Preventive and Social Medicine (NIPSOM),Mohakhali, Dhaka-1212

3. Professor and Chairman, Department of Oncology, Bangabandhu Sheikh Mujib Medical University, Dhaka

4. Consultant, Faculty of Dentistry, Bangabandhu Sheikh Mujib Medical University, Dhaka that affects their lives. Women's empowerment in a family includes the women's place or position in terms of making decision about one's private concerns and those of ones intimates. Women's status is the degree of women's access to and control over material resources (including food, income, land and other forms, of wealth) and social resources (including knowledge, power and prestige) within the family, in the community, and in the society at large. ${ }^{1}$ Of 1.3 billion people who live in absolute poverty around the globe, $70 \%$ are women. For these women, poverty doesn't just mean scarcity and want. It means rights denied, opportunities curtailed and voices silenced. The overwhelming majority of the labor that sustains life- growing food, cooking, raising children, caring for the elderly, maintaining a house, hauling water-is done by women, and universally this work is accorded low status and no pay. The ceaseless cycle of labor rarely shows up in economic analyses of a society's production and value. Women earn only $10 \%$ of the world's income. Where women work for money, they may be limited to a set of jobs deemed suitable for womeninvariably low pay, low status positions. Women own less than $1 \%$ of the world's property. ${ }^{2}$ Anecdotally, men have traditionally been more likely than women to make household savings and investment decisions, but there is evidence to suggest that women's involvement in household financial decision making has been increasing. ${ }^{3,4}$ There is a common perception in development literature that increased participation of women in savings and credit activities or economic attainment will empower women. Thus, self-help groups are seen as an important tool for empowering women. There is also the perception that economic attainment will empower women's status in family and in the community, giving them more power to participate in decision-making process. ${ }^{5}$ Ensuring that women have a greater voice in household and community decisions is critical to fulfilling their rights as well as the rights of children. While international agencies, governments, civil society organizations and women themselves have made significant progress in promoting a more egalitarian, dynamic, much remains to be done. ${ }^{6}$

The socio-cultural situation and family structure of our country remains unchanged for centuries. Peoples belief and understanding have not changed despite of modernization and ongoing changes all around. Their life style still follows the pattern that has been followed by their ancestors for thousands of years. As women become economically productive, their spheres of influence increase. Evidence from Demographic and Health Surveys suggests that in some developing countries much of the impact of women's overall decision making power is concentrated at the community level. Across the developing world, studies show that women's participation in community initiatives can have long lasting benefits for women. Considering this view, this study was aimed to assess the women decision making power or empowerment in the household issues. The findings of the study would help in 
implementing the programmes by policy makers, programme managers achieving the millennium development goals.

\section{Materials and Methods:}

This was a descriptive type of cross sectional study conducted among the women in the selected areas of rural and urban areas with a view to assessing their empowerment and participation of decision making process in different household issues. The study was carried out in women residing at Zigatola of Dhaka City and village of Killandi in Arayhazar Upazila in Narayanganj. The study was conducted for a period of six months starting from January 2008 to June 2008. A total of 206 women were selected purposively, 101 from rural and 105 from urban area. For smooth conduction of the study, an interview schedule was developed consisting of two parts. The first part of the interview schedule consisted of socio-demographic status related questions and the second part consisted of empowerment or household decision making issues. The questionnaire was finalized following pretest. The respondents were informed about the purpose of the study and their voluntary participation was sought. Before interviewing, a written informed consent was taken assuring that the collected data would be kept confidential. Data were collected, checked and cross-checked (triangulation) before entry into a computer and analyzed with the help of SPSS Windows Software Programme (version 16). The data were presented in simple frequency tables and also presented in diagram. Cross tabulation was done to find any association between two variables and was tested by Chi-square. To find out the composite household decision making process, an empowerment scale was developed based on all the question related to household decision making issues by Principal Component Analysis (PCA), a factorial analysis with a view to reducing the variable into one.

\section{Results:}

Socio-demographic characteristics: The mean age of the respondents and their husbands was 34.2(SD 7.5) years and 42.4(SD 8.9) years respectively with spousal age difference was $8.13(\mathrm{SD} 4.2$ ) years ranging from 0 to 34 years. It was found that majority of the respondents were Muslim (93.2\%). Regarding the level of education indicated that highest percentage of respondents had secondary level of education (25.7\%) followed by primary (21.4\%), graduate (16.5\%), masters (14.6\%) and (6.3\%) were illiterate. In contrast to the husband's level of education, highest percentage was graduate $(27.7 \%)$ followed by masters (21.4), secondary (18\%), higher secondary (15.5\%), primary (12.6\%) and illiterate $10(4.9 \%)$. The mean number of children was 2 ranging from 0 to 7 . More than two fifths of their husbands were engaged in business (44.4\%) followed by private service (31.3\%), government service (12.6\%), day labourer (6.6\%). The median family size of the respondents was Taka 18000 ranging from Taka 2000 to 150000. Majority of the respondents living in the pucca house (60.2\%) followed by semi-pucca house (22.8\%) and (17\%) living in the katcha house (Table-I).
Table-I : Socio-demographic characteristics $(n=206)$

\begin{tabular}{|c|c|c|c|}
\hline Variables & No. & $\%$ & Mean ( SD), Range \\
\hline \multicolumn{4}{|c|}{ Age in years (respondent) } \\
\hline$<35$ & 110 & 53.4 & 34.2(SD 7.5) yrs; \\
\hline$\geq 35$ & 96 & 46.6 & Range $=20$ to 55 years \\
\hline \multicolumn{4}{|c|}{ Age in years (husband) } \\
\hline$<40$ & 84 & 40.8 & 42.4(SD 8.9) yrs; \\
\hline e”40 & 122 & 59.2 & Range $=23-74$ yrs \\
\hline \multicolumn{4}{|c|}{ Age at marriage (years) } \\
\hline$<20$ & 96 & 46.6 & 20.4(SD 8.1) yrs; \\
\hline$\geq 20$ & 110 & 53.4 & Range $=14$ to 36 yrs \\
\hline \multicolumn{4}{|c|}{ Spousal age difference (years) } \\
\hline$<10$ & 133 & 64.6 & 8.13( SD 4.2) yrs; \\
\hline$\geq 10$ & 73 & 35.4 & Range $=0$ to 34 yrs. \\
\hline \multicolumn{4}{|l|}{ Residence } \\
\hline Rural & 101 & 49.0 & \\
\hline Urban & 105 & 51.0 & \\
\hline \multicolumn{4}{|l|}{ Religion } \\
\hline Islam & 192 & 93.2 & \\
\hline Hinduism & 14 & 6.8 & \\
\hline \multicolumn{4}{|c|}{ Level of education (respondent) } \\
\hline Illiterate & 13 & 6.3 & \\
\hline Primary & 44 & 21.4 & \\
\hline Secondary & 53 & 25.7 & \\
\hline Higher secondary & 32 & 15.5 & \\
\hline Graduate & 34 & 16.5 & \\
\hline Masters & 30 & 14.6 & \\
\hline \multicolumn{4}{|c|}{ Level of education (husband) } \\
\hline Illiterate & 10 & 4.9 & \\
\hline Primary & 26 & 12.6 & \\
\hline Secondary & 37 & 18.0 & \\
\hline Higher secondary & 32 & 15.5 & \\
\hline Graduate & 57 & 27.7 & \\
\hline Masters & 44 & 21.4 & \\
\hline \multicolumn{4}{|c|}{ Number of children } \\
\hline $0-2$ & 145 & 70.4 & 2.09(SD1.12); \\
\hline$\geq 3$ & 61 & 29.6 & Range = 0-7; Median=2 \\
\hline \multicolumn{4}{|c|}{ Occupation (respondent) } \\
\hline Housewife & 145 & 70.4 & \\
\hline Others & 61 & 29.6 & \\
\hline \multicolumn{4}{|c|}{ Occupation (husband) } \\
\hline Govt service & 25 & 12.1 & \\
\hline Pvt. service & 62 & 30.1 & \\
\hline Business & 88 & 42.7 & \\
\hline Manual job & 31 & 15.0 & \\
\hline \multicolumn{4}{|c|}{ Monthly family income (Tk.) } \\
\hline Up to 10000 & 58 & 28.2 & Median = Tk. 18000.0; \\
\hline $10001-20000$ & 62 & 30.1 & Range $=$ Tk. 2000 to 150000 \\
\hline$\geq 20001$ & 86 & 41.7 & \\
\hline \multicolumn{4}{|c|}{ Housing condition } \\
\hline Katcha & 35 & 17.0 & \\
\hline Semi-pucca & 47 & 22.8 & \\
\hline Pucca & 124 & 60.2 & \\
\hline
\end{tabular}


Women empowerment: To assess the level of women empowerment or decision making process, a series of questions were asked with a view to assess the level of participation in different household and family matters. Table-II shows different areas of concern. The highest percentage of respondents participated in decision making process of purchasing their own saris (84.5\%) followed by Freedom of purchasing cosmetics (84.5\%), opinion for children's admission in school (82.0\%), opinion seeks for childbirth (82.0\%), opinion for family planning (79.1\%), freedom of purchase children's clothing (78.6\%), treatment autonomy for children (76.7\%), treatment autonomy for own (70.9\%), freedomness for expenditure (66.0\%), knowledge about inheritance law (66.0\%), knowledge about inheritance law (66.0\%), freedom of expenditure for own (58.7\%), freedom of saving money (57.3\%), freedom of purchasing ornaments (56.8\%), free to move outside (51.5\%), opinion for land dispute (48.5\%), freedom to travel (45.6\%), freedom purchase of properties for own $33.0 \%$ ) and whether micro credit holder (17.0\%). On the basis of 19 variables, a composite level of women empowerment was assessed by Principal Component Analysis (PCA) using computer simulation and categorized into three groups such as poor (score 1-82), fair (score 83-122) and good (score e"123). It was found that (39.8) had poor level of empowerment, (19.4\%) had fair empowerment and (40.8\%) had good level women empowerment (Fig..-1).

Table-II : Distribution of the respondents and issues related to women's decision making $(n=206)$

\begin{tabular}{lcc}
\hline $\begin{array}{l}\text { Issues of women participation in } \\
\text { different issues }\end{array}$ & Frequency & $\%$ \\
\hline Freedom of purchase saris & 176 & 85.4 \\
Freedom of purchasing cosmetics & 174 & 84.5 \\
Opinion for children's admission in school & 169 & 82.0 \\
Opinion seeks for childbirth & 169 & 82.0 \\
Opinion for family planning & 163 & 79.1 \\
Freedom of purchase children's clothing & 162 & 78.6 \\
Treatment autonomy for children & 158 & 76.7 \\
Treatment autonomy for own & 146 & 70.9 \\
Freedomness for expenditure & 136 & 66.0 \\
Knowledge about inheritance law & 136 & 66.0 \\
Freedom of expenditure for own & 121 & 58.7 \\
Freedom of saving money & 118 & 57.3 \\
Freedom of purchasing ornaments & 117 & 56.8 \\
Free to move outside & 106 & 51.5 \\
Opinion for land dispute & 100 & 48.5 \\
Freedom to travel & 94 & 45.6 \\
Freedom purchase of properties for own & 68 & 33.0 \\
Whether micro credit holder & 35 & 17.0 \\
\hline
\end{tabular}

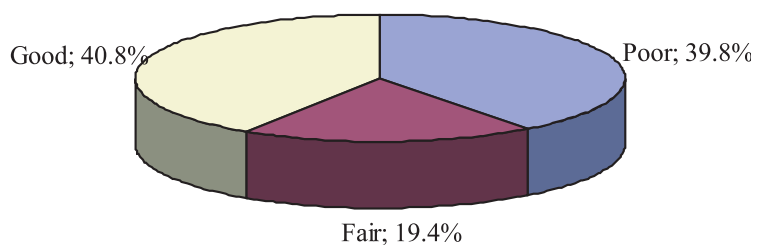

Fig.-1: Level of women empowerment $(n=206)$
Table-III: Relationship between women empowerment and selected socio-demographic characteristics

\begin{tabular}{|c|c|c|c|c|c|}
\hline \multirow[t]{2}{*}{ Variables } & \multirow[t]{2}{*}{ No. } & \multicolumn{4}{|c|}{ Women empowerment $\mathrm{p}$ value } \\
\hline & & Good & Fair & Poor & \\
\hline \multicolumn{6}{|l|}{ Age in years } \\
\hline$<35$ & 110 & 41.8 & 18.2 & 40.0 & 0.882 \\
\hline$\geq 35$ & 96 & 39.6 & 20.8 & 39.6 & \\
\hline \multicolumn{6}{|c|}{ Age in years (Husband) } \\
\hline$<40$ & 84 & 42.9 & 20.2 & 36.9 & 0.779 \\
\hline$\geq 40$ & 122 & 39.3 & 18.9 & 41.8 & \\
\hline \multicolumn{6}{|l|}{ Residence } \\
\hline Urban & 105 & 59.0 & 21.9 & 19.0 & 0.001 \\
\hline Rural & 101 & 21.8 & 16.8 & 61.4 & \\
\hline \multicolumn{6}{|l|}{ Religion } \\
\hline Islam & 192 & 41.7 & 20.8 & 37.5 & 0.027 \\
\hline Hinduism & 14 & 28.6 & & 71.4 & \\
\hline \multicolumn{6}{|c|}{ Level of education (respondent) } \\
\hline Illiterate & 13 & 23.1 & 15.4 & 61.5 & 0.001 \\
\hline Primary & 44 & 29.5 & 11.4 & 59.1 & \\
\hline Secondary & 53 & 30.2 & 24.5 & 45.3 & \\
\hline Higher secondary & 32 & 40.6 & 21.9 & 37.5 & \\
\hline Graduate & 34 & 44.1 & 29.4 & 26.5 & \\
\hline Masters & 30 & 80.0 & 10.0 & 10.0 & \\
\hline \multicolumn{6}{|c|}{ Level of education (Husband) } \\
\hline Illiterate & 10 & 20.0 & 30.0 & 50.0 & 0.001 \\
\hline Primary & 26 & 19.2 & 15.4 & 65.4 & \\
\hline Secondary & 37 & 35.1 & 13.5 & 51.4 & \\
\hline Higher secondary & 32 & 25.0 & 28.1 & 46.9 & \\
\hline Graduate & 57 & 43.9 & 21.1 & 35.1 & \\
\hline Masters & 44 & 70.5 & 15.9 & 13.6 & \\
\hline \multicolumn{6}{|c|}{ Occupation (respondent) } \\
\hline Housewife & 145 & 35.2 & 20.7 & 44.1 & 0.039 \\
\hline Working women & 61 & 54.1 & 16.4 & 29.5 & \\
\hline \multicolumn{6}{|l|}{ Occupation (husband) } \\
\hline Government service & 25 & 48.0 & 16.0 & 36.0 & 0.035 \\
\hline Private service & 62 & 56.5 & 17.7 & 25.8 & \\
\hline Business & 88 & 34.1 & 20.5 & 45.5 & \\
\hline Manual job & 31 & 22.6 & 22.6 & 54.8 & \\
\hline \multicolumn{6}{|l|}{ Age at marriage (yrs) } \\
\hline$<20$ & 96 & 35.4 & 18.8 & 45.8 & 0.229 \\
\hline$\geq 20$ & 110 & 45.5 & 20.0 & 34.5 & \\
\hline \multicolumn{6}{|c|}{ Spousal age difference (yrs) } \\
\hline$<10$ & 133 & 44.4 & 18.8 & 36.8 & 0.353 \\
\hline$\geq 10$ & 73 & 34.2 & 20.5 & 45.2 & \\
\hline \multicolumn{6}{|l|}{ No. of children } \\
\hline $0-2$ & 145 & 46.2 & 19.3 & 34.5 & 0.030 \\
\hline$\geq 3$ & 61 & 27.9 & 19.7 & 52.5 & \\
\hline \multicolumn{6}{|l|}{ Housing condition } \\
\hline Katcha & 35 & 20.0 & 22.9 & 57.1 & 0.001 \\
\hline Semi-pucca & 47 & 29.8 & 14.9 & 55.3 & \\
\hline Pucca & 124 & 50.8 & 20.2 & 29.0 & \\
\hline \multicolumn{6}{|c|}{ Monthly income (Tk.) } \\
\hline Up to 10000 & 58 & 34.5 & 8.6 & 56.9 & 0.044 \\
\hline $10001-20000$ & 62 & 30.6 & 27.4 & 41.9 & \\
\hline$\geq 20001$ & 86 & 52.3 & 20.9 & 26.7 & \\
\hline
\end{tabular}


Relationship between women empowerment and sociodemographic characteristics: Bi-variate analysis revealed that level of women's empowerment was found to be high among the respondents living in urban areas, less number of children, religion in Islam, higher level of education of both husband and wife, working status of husband and wife, monthly family income and living in pucca house $(\mathrm{p}<0.05)$. However, no statistically significant association was found between current age of both husband and wife, age at marriage and spousal age difference ( $\mathrm{p}>0.05$ ) (Table-III).

\section{Discussion:}

Women's autonomy or empowerment is an essential precondition for the elimination of world poverty and the upholding of human rights in particular at the individual level, it helps building a base for social change. In Bangladesh, women constitute about half of the total population of which $80 \%$ live in rural areas. But their status has been ranked the lowest in the world on the basis of twenty indicators related to health, marriage, children, education, employment and social equality (NCBP, 2000). ${ }^{7}$ It is fact that in a patriarchal society like Bangladesh, women are ascribed a lower status as men who have the sovereign power to control households and society as a whole, while women are often secluded in their homes. The World Bank study in Bangladesh highlights that women have limited role in household decision-making, limited access and control over household resources (physical and financial assets), low level of individual assets, heavy domestic workloads, restricted mobility and inadequate knowledge and skills that leading to women's vulnerability (Sebstad and Cohen (2002). ${ }^{8}$ Considering this gloomy picture of women's situation into account, this study was undertaken to address the following objective to analyze and determine the nature and extent of women's participation and factors influencing it.

The level of women empowerment or autonomy in participation in different household issues was found to be high among the respondents living in urban areas and poor level of empowerment was found to be high among the rural women and the difference was statistically significant $(\mathrm{p}<0.05)$. Urban women are mostly literate, they have touch with modern amenities and they usually enjoy freedom, so the level of empowerment was high. Speizer, Whittle, and Carter (2005) ${ }^{9}$ in their study found that living in a rural area were each associated with male centered decision making. There was no statistically significant association was found between level of women level of participation of women and age of the respondents and their husband $(p>0.05)$ though the women aged 30 years and above enjoyed better autonomy than the younger age group. Dhanabaghyam and. Romanujam (2005) in their study found similar results. ${ }^{1}$ This might be fact that older women with long duration of marital life had to develop their voice. On the contrary, the younger with immature mental makeup did not establish strong voice in the family. Age at marriage and spousal age difference were important factors of women autonomy in the household matters. Though the study did not find any statistically significant association ( $p>0.05$ ) between level of participation and age at marriage and spousal age difference. But analysis revealed that women married at age 20 years and less spousal age difference enjoyed more autonomy. However, Dhanabaghyam and Ramanujam (2005) had shown that age at marriage over 18 years enjoyed more autonomy than the younger counterpart. But a reverse picture was found in the same study that spousal age difference 10 years and above enjoy more autonomy than the less than 10 years. Spousal age difference 10 or more, play more independent role in family matters. ${ }^{1}$ In this study the proportion of good level of participation was found to be high among the respondents believe in Islam (41.7\%) whereas poor level of participation was found among the respondents believes in Hinduism (71.4\%). Though the study found a statistically significant association between level of women participation and religion $(\mathrm{p}<0.05)$, but the association be spurious as the sample size was so small with highest preponderance of Muslim respondents in our country context.

Evidences from developing countries reveal several major points of interest concerning the direct relationship between woman education and fertility (Jejeebhoy, 1995). ${ }^{10}$ In most societies, there appears to be a threshold level of education beyond which marked differentials in fertility are generated. Within countries, similarly, the impact of women's education on fertility tends to be more consistently inverse in better developed regions or urban areas than in less developed or rural areas. The present study showed a significant relationship between level of education and level of autonomy. Study revealed that women with higher education and above enjoyed more a autonomy than the illiterate and primary level of education. Similar results was found by Dhanabaghyam and Ramanujam in their study. They found that that, educated women's had more participation in household decision. ${ }^{1}$ Speijer, Whittle and Carter (2005) in their study found that the area male centered decision making family when women had less than secondary education. ${ }^{9}$

Occupation of women is an important factor for women empowerment which indicated that housewives are less empowered than those who are engaged in job and the difference was statistically significant $(p<0.05)$. The study of Dhanabaghyam and Ramanujam (2005) and Kumar's (2006) study were similar to this study. ${ }^{1,5}$ Higher monthly income, of respondents contributed family, they had good level of empowerment. Malhotra, Schuler and Boender (2002) ${ }^{3}$ argued that empowerment is a process, by which women gain greater 
control over material and intellectual resources which will assist them to increase their self reliance, and enhance them to assert their independent rights, and challenge the ideology. This will also enable them to organize themselves to assert their autonomy to make decisions and choices, and ultimately eliminate their own subordination in all the institutions and structures of society. The present study revealed that empowered women with job and go outside from the house, they know more things than a housewife and they give money to the family. As a result the family benefited two folds, that is earning an independent income shown to lead to increase in women's ability to exercise "voice" in the household decision making process and the women's income increase the well being of the family. This is important as a reflection of enhanced power at the household level resulting in greater choice in household resource allocation, especially for those respondents living in pucca house, they had more decision making role in household matters. Though the study did not find any statistically significant association between level of decision making authority and work status ( $\mathrm{p}>0.05)$, but data showed a higher preponderance autonomy with working women. Study found a significant association with housing condition that is living in pacca house enjoyed more autonomy than the others $(\mathrm{p}<0.05)$. Speizer, Whittle and Carter $(2005)^{9}$ and Dhanbaghyam and Ramanujam $(2005)^{1}$ study found similar association. The housing condition might be a proxy of economic status that is those people who live in a katcha house, mostly they were illiterate and don't have any right to say anything in their family matters.

The major weakness of the study is its representativeness, small sample size and strength is comprehensive information on participating women and their household matters. Another weakness of the study was, on the other hand, is the crosssectional design which may, in some aspects, obscure the temporality. For example, women's autonomy is partly derived from the individual factor; it is, therefore, difficult to clearly establish the temporality and causality of the effects. However, this problem, fortunately, does not affect the main focus of this study. Education is a long-term and relatively stable characteristic, like this other factors influencing the women autonomy or empowerment.

\section{References:}

1. Dhanabaghyam N, Ramanujam C. Women's Role in Family Decision Making. Population Research Centre, Gandhigram Institute or Rural Health and Family Welfare Trust, Gandhigram, Tamil Nadu. 2005

2. Women empowerment. ink:www.care.org/newsroom/ publication/whitepapers/women_and empowerment.pdfsujin.com.np (Access January 08 2008)

3. Malhotra A, Schuler S.R, Boender C. Measuring Women's Empowerment as a variable in International Development. The Gender and Development Group of the World Bank, 2002 June, 28

4. Bernasek A, Bajtelsmit V.L. Predictors of Women's Involvement in Household Financial Decision Making. Financial Counseling and Planning, 2002; 13(2):

5. Kumar A. Self-Help Groups, Women's Health and Empowerment: Global Thinking and Contextual Issues. Jharkhabad Journal of Development and Management. 2006; 4(3): 2061-79

6. Women and Children: The double dividend of gender equality, The state of the World's children 2007, URL: www.unicef.org (Retrieved on: 2008, Jan 2)

7. NCBP (2000) Gender Equality, Development and Peace for the Twenty-first Century, NGO Committee on Beijing Plus Five in Bangladesh, Dhaka : Women for Women - A Research and Study Group.

8. Sebstad J and Cohen M. Microfinance, Risk Management and Poverty. Washington D.C.: CGAP, World Bank. 2001

9. Speizer I.S, Whittle L, Carter M. Gender Relations and Reproductive Decision Making in Honduras. International Family Planning Perspectives 2005 Sep; 31(3):

10. Jejeebhoy, S.J. Women's Education, Autonomy and Reproductive Behaviour: Experience from Developing Countries. Oxford: Clarendon Press. 1995. 